\title{
Freedom of Religion in the Genocidal Process and Group Destruction in the Holocaust and Armenian and Cambodian Genocides
}

\author{
Melanie O’Brien
}

Human rights are freedoms that are inherent to all persons, which states are obligated to protect. The atrocities of World War Two, in particular the annihilation of Jews in the Holocaust, shocked the global community into the creation of today's human rights legal system. Traditionally, international law was concerned with the rights and regulations of states. Following the Holocaust however, other actors (including individuals) were included in international law, based on the idea that states should not be free to treat persons within their territory as they wish and, in particular, should not be free to persecute and kill. The sentiment was that people should be respected and accorded rights to be able to live with dignity and liberty, within a broader desire for democratic rule of law. ${ }^{94}$ Dignity and freedom are the essence of human rights, and are to be enjoyed by all without discrimination as to race, gender, religion,

94 J.S. Mill, On Liberty and Other Essays (Oxford: Oxford University Press, 1991).

How to cite this book chapter:

O’Brien, M. 2020. Freedom of Religion in the Genocidal Process and Group

Destruction in the Holocaust and Armenian and Cambodian Genocides. In:

Marczak, N. and Shields, K. (eds.) Genocide Perspectives VI: The Process and the

Personal Cost of Genocide. Pp. 33-52. Sydney: UTS ePRESS. DOI: https://doi .org/10.5130/aaf.c. License: CC BY-NC-ND. 
ethnicity, sexuality, nationality, language, political or other opinion, disability, or any other reason. This is the universality and inalienability of human rights: everyone, everywhere is entitled to human rights. Protection of human rights is fundamental.

Genocide is a process, ${ }^{95}$ throughout which many human rights violations occur, usually on a mass scale. The process begins with violations such as restrictions on freedom of expression and freedom of movement, escalating to violations of rights to family and health, before intensifying to violations of right to freedom from torture and cruel, inhuman and degrading treatment, and right to life. ${ }^{96}$ This chapter will consider one particular human rights violation in genocide: violation of the right to freedom of religion.

Genocide consists of multiple crimes, including non-physical-extermination crimes: causing serious bodily or mental harm to members of national, ethnical, racial, or religious groups; and forcibly transferring children of the group to another group. Such crimes are essential in determining genocide and must not be suppressed from deliberations over the definition of genocide or the prosecution of perpetrators. While genocidal crimes may manifest in many forms, this essay focuses on violations of freedom of religion, which amount to criminal conduct as they cause serious bodily or mental harm, and include forcible transfer of children (for religious conversion) and killing members of a group (religious leaders).

Some groups are targeted for genocide because of religion, and are subject to substantial violations of their right to freedom of religion. Nonetheless, as will

95 On genocide as a process, see for example, Martin Shaw, What is Genocide? (Cambridge: Polity Press, 2015), 101-3; Sheri P Rosenberg, 'Genocide Is a Process, Not an Event', Genocide Studies and Prevention 7, no. 1 (2012): 17-23; Scott Straus, 'Contested Meanings and Conflicting Imperatives: A Conceptual Analysis of Genocide', Journal of Genocide Research 3, no. 3 (2001):349-75; Sheri P Rosenberg and Everita Silina, 'Genocide by Attrition: Silent and Efficient', in Genocide Matters: Ongoing Issues and Emerging Perspectives, eds. Joyce Apsel and Ernesto Verdeja (Abingdon: Routledge, 1999), 106-26; Helen Fein, 'Genocide by Attrition 1939-1993: The Warsaw Ghetto, Cambodia, and Sudan: Links Between Human Rights, Health, and Mass Death', Health and Human Rights 2, no. 2 (1997): 14; Leo Kuper, Genocide: Its Political Use in the Twentieth Century (New Haven: Yale University Press, 1982); Helen Fein, Accounting for Genocide: National Responses and Jewish Victimization During the Holocaust (New York: Free Press, 1979), 60; 'The 8 Stages of Genocide', Genocide Watch, 1998, http://www .genocidewatch.org/aboutgenocide/8stagesofgenocide.html; 'The Ten Stages of Genocide', Genocide Watch, 2016, http://genocidewatch.net/genocide -2/8-stages-of-genocide/.

96 These violations are somewhat linear, but there are also many overlapping stages. 
be demonstrated by the case studies in this chapter, even if a group is targeted for their nationality, race, or ethnicity, genocidal regimes have a tendency to fixate on destruction of religion as they execute genocide. This chapter examines the specific targeting of religion itself; how genocidal regimes breach the human right of freedom of religion as part of the destruction of that group as a social structure. Analysis will be offered of violations of freedom of religion as carried out by the Nazis, Committee of Union and Progress (CUP or Young Turks), and Khmer Rouge respectively in the Holocaust, and the Armenian and Cambodian genocides. The chapter will demonstrate how this particular human rights violation contributes to genocide, regardless of whether the group targeted for destruction is categorised as a religious group. This essay will conclude with what can be appropriated from these case studies for prevention and punishment of genocide.

\section{Right to freedom of religion}

The right to freedom of religion is enshrined in the Universal Declaration of Human Rights (article 18) and the International Covenant on Civil and Political Rights (article 18). It is considered a 'far-reaching and profound' human right, as it is part of the sweeping human right to thought, conscience and religion. ${ }^{97}$ It protects theistic, non-theistic, and atheistic beliefs, and religions of any age or group size. Also included is the right not to profess any religion or belief. ${ }^{98}$

The right protects freedom to manifest religion or belief in worship, observance, practice, and teaching. This is an inclusive freedom covering: ritual and ceremonial acts; building of places of worship; use of ritual formulae and objects; display of symbols; observance of holidays and days of rest; dietary requirements; wearing of distinctive clothing or head coverings; participation in rituals associated with certain stages of life; use of a particular language customarily spoken by a group; choice of religious leaders, priests, and teachers; establishment of seminaries or religious schools; and preparation and distribution of religious texts or publications. ${ }^{99}$ It is prohibited to coerce or impair the right to have or adopt a religion or belief, or to restrict access to services (medical, education, and etcetera) based on religion. ${ }^{100}$

${ }^{97}$ Human Rights Committee General Comment No. 22, UN Doc. CCPR/C/21/ Rev.1/Add.4, 27 Sept. 1993, para. 1.

98 Ibid., para. 2.

99 Ibid., para. 4.

${ }^{100}$ Ibid., para. 5; Heiner Bielefeldt, Nazila Ghanea, and Michael Wiener, Freedom of Religion or Belief: An International Law Commentary, Oxford Scholarly Authorities on International Law (Oxford: Oxford University Press, 2016), 56. 
Limitations on the right to freedom of religion are permitted. However, as with the general rule on limitations on human rights, such limitations are only permissible when prescribed by law and when necessary to protect public safety, order, health, or morals. No limitation is authorised with regards to the prohibition on coercion of religion and on religious education. This equates the prohibition on coercion and education with the prohibitions on slavery and torture, from which derogations are also not authorised, in order to ensure human dignity (an underlying principle of human rights). Even more specifically, '[r] estrictions may not be imposed for discriminatory purposes or applied in a discriminatory manner.' ${ }^{101}$

Minority religions are not to be discriminated against. The terminology used by the United Nations Human Rights Committee indicates that violation of freedom of religion is inherently linked to discrimination, persecution, and even violence:

In particular, certain measures discriminating against [adherents of minority religions or non-believers], such as measures restricting eligibility for government service to members of the predominant religion or giving economic privileges to them or imposing special restrictions on the practice of other faiths, are not in accordance with the prohibition of discrimination based on religion or belief and the guarantee of equal protection under article $26 .^{102}$

Freedom of religion is a human right that, while granted to the individual, has inherent communal and social aspects. Bielefeld et al. suggest that ' $\mathrm{h}] \mathrm{hman}$ rights have a strong positive bearing on communities, since they are always exercised in a social context. ${ }^{\prime}{ }^{103}$ Religion is an individual choice, but is often practiced communally and seen as very significant socially. It exists in many cultures as a defining element of that culture, of that group, even if that group is considered national, ethnical, or racial. Therefore, violation of the right to freedom of religion can lead to communal and social disintegration.

Writing of his experience in the Holocaust, Jean Améry described the violation of human rights during the genocide process as a destruction of his society and community: 'The functionary of an authoritarian system who beats me arbitrarily, does not merely violate my body; he rips apart ... the social contract within whose limits any human conduct, across all societal roles and situations, must always remain.' ${ }^{104}$ Améry noted that 'dignity can be bestowed only

${ }^{101}$ HRC GC No. 22, para. 8.

102 HRC GC No. 22, para. 9.

103 Bielefeldt, Ghanea, and Wiener, Freedom of Religion, 69.

104 Améry speaks specifically of this struggle: Jean Améry, Jenseits von Schuld und Sühne: Bewältigungsversuche eines Überwältigten (Stuttgart: 
by society', and that dignity is connected to trust in the world and the social contract. ${ }^{105}$ Freedom of religion is part of the fundamental right to human dignity, and part of the social contract. Destruction of dignity and social binds is a substantial element of the destruction of a group in genocide; one that survivors struggle to reclaim and to deal with. ${ }^{106}$

\section{Violations during the Armenian Genocide}

The Ottoman Empire was a fairly tolerant pluralistic empire. A variety of groups of different ethnicities and religions co-existed without being persecuted. However, this did not mean that all groups-particularly minority groups-had equality. Armenians were a distinct minority group in the Ottoman Empire: they were Christian in a Muslim majority. ${ }^{107}$ Moreover, Armenians were a distinctive group, with their own religion, language, and culture. They were a millet, a religious community within the Empire, with well-defined statuses, duties, and obligations, and a great deal of autonomy, including the right to practice their religion. ${ }^{108}$ Yet this status also resulted in legalised discrimination in certain areas of life, such as multiple taxes and exclusion from military service. ${ }^{109}$ As Melson explains, 'This was the explicit agreement that dhimmis [people of the scripture] were never to consider themselves the equals of Muslims. The Ottoman state considered Muslim superiority to be both just and natural, and the necessary if not merely sufficient condition for its continued tolerance of inferior minorities. ${ }^{\prime 10}$ Christians were second-class citizens due to their religion. Muslims referred to them as Gavur (or Kafir)-unbeliever or 'infidel', a word with emotional and derogatory overtones.

Klett-Cotta, 1977), 64, cited in Bielefeldt, Ghanea, and Wiener, Freedom of Religion, 80.

105 Jean Améry, At the Mind's Limits: Contemplations By a Survivor on Auschwitz and Its Realities (Bloomington: Indiana University Press, 1980), 28, 89.

106 Ibid.

107 The Armenians were not the only Christian group to be targeted for destruction by the Ottoman leaders. Others such as the Assyrian and Greek Christians were also victims of persecution and massacres; Benny Morris and Dror Zeevi, The Thirty-Year Genocide: Turkey's Destruction of Its Christian Minorities, 1894-1924 (Cambridge: Harvard University Press, 2019).

108 Robert Melson, Revolution and Genocide: On the Origins of the Armenian Genocide and the Holocaust (Chicago: University of Chicago Press, 1992), 54.

109 Ibid.

${ }^{110}$ Ibid., 56. 
In the 1800s, despite anti-Christian sentiment, Armenians were granted rights such as taxation rights. ${ }^{111}$ However, these rights did not materialise. Consequently, Armenians began to push for implementation of these rights. When the Young Turks came to power in 1908, the Armenian campaign for rights coincided with a loss of territory for the Ottoman Empire. Consequently, the Young Turks linked the Armenian push for rights to the idea that Armenians were seeking independence and collaborating with Russia. This was part of the justification provided for what became the genocide of the Armenians. In doing this, the Armenians were targeted as an ethnic (or national) and religious group. Principally, their Christianity held them apart and sculpted them as outsiders in an empire that was to become today's nation of Turkey. The success of the Armenian minority 'gave the appearance that it was challenging a traditional and hierarchical, Muslim and imperial, religious and political order. ${ }^{112}$

Officially, the Armenian Genocide began on 24 April 1915. However, there were massacres and human rights violations preceding this, from the $1890 \mathrm{~s}$. From 1894-96, massacres were carried out under Sultan Abdul Hamid II against Armenians and other Christian minorities of the Ottoman Empire. ${ }^{113}$ Up to 300,000 Armenians were killed in the Hamidian massacres. ${ }^{114}$ As part of these pogroms, forced Islamisation also took place, with approximately 40,000-100,000 Christians forcibly converted. Churches and monasteries were pillaged, profaned, and demolished; churches were converted into mosques; priests and vicars ${ }^{115}$ were killed. ${ }^{116}$ The Christianity of these groups was used against them: 'Ittihadists, like Sultan Abdul Hamid, employed religion as an instrument of propaganda to mobilise the Muslim masses.' ${ }^{117}$

111 Ruben Safrastyan, Ottoman Empire: The Genesis of the Program of Genocide (1876-1920) (Yerevan: National Academy of Sciences, 2011), 32-99.

${ }_{112}$ Melson, Revolution and, 53.

113 Anahit Khosroeva, 'The Assyrian Genocide in the Ottoman Empire and Adjacent Territories', in The Armenian Genocide: Cultural and Ethical Legacies, ed. Richard G. Hovannisian (New Brunswick: Transaction Publishers, 2007), 26; Deborah Mayersen, On the Path to Genocide: Armenia and Rwanda Reexamined (New York: Berghahn Books, 2014), 40-60.

114 Melson, Revolution and, 47.

115 'Vicar' translated from 'desservant' in French texts (author's translation).

116 Mayersen, On the Path, 49; Armenian National Archives document, 'Liste abrégée, relatant exclusivement les profanations d’églizes, les conversions forcées et les assassinats d'ecclésiastiques, qui ont eu lieu lors des massacres commis dans les provinces de la Turquie habitées par les Arméniens, depuis les derniers jours du mois de septembre 1895', undated, with handwritten notations dated 1895/6.

117 Simon Payaslian, 'The Destruction of the Armenian Church during the Genocide', Genocide Studies and Prevention 1, no. 2 (2006): 156. Ittihadists were the Committee of Union and Progress; initially a secret society 
The anti-Christian sentiment grew under the Young Turks, for whom priority was Turkification of the empire, including Islamisation. ${ }^{118}$ Discrimination against Christians grew. No clocks were permitted on church towers, and only wooden bells were allowed. Church towers could not be higher than mosque minarets; Christians were prohibited from having houses higher than Muslim houses.

From April 1915 onwards, the Armenians were subject to a significant range of well-organised crimes. As part of this, freedom of religion was specifically targeted. Supreme religious leaders were deported as part of the deconstruction of the Armenian Church as an entity. ${ }^{119}$ Priests and other religious leaders were specifically targeted in massacres. Unlike the killings of ordinary people, religious leaders were often tortured publicly before being killed. Survivor testimony demonstrates that ' $\mathrm{t}$ ] he clergy were treated with particular severity, priests were killed through brutal torturing, their beards were torn out or singed, eyes blinded, tongues and noses cut off and so on. ${ }^{120}$ One survivor recounted:

From their stories I learned that our priest (Ter Yeghiazar) and the primate (Ter Yeghishe), and all prominent Armenians were on the kaymakam's order to be slaughtered. And cut into pieces with daggers. Before murdering them, their beards would be removed by flaying their skin and displayed on the market wall as an ornament. ${ }^{121}$

Another described the beating to death of a priest with sticks, after which ' $\mathrm{t}$ ] hey filled his mouth with rubbish and threw him in the river.' ${ }^{122}$

In addition to targeting religious leaders, religious buildings and icons were also specifically attacked. Churches were ransacked, particularly for valuable religious icons; less valuable artefacts were destroyed. Churches were often profaned, for the specific objective of humiliating the religion and the religious. Further, churches were converted into stables, which resulted in profanation

formed in 1889, the CUP later became a political party that merged with the Young Turks.

118 Melson, Revolution and, 138; Raymond Kévorkian, The Armenian Genocide: A Complete History (London: I.B. Tauris, 2011), 189-200.

119 Payaslian, 'The Destruction', 160-61.

${ }^{120}$ National Archives of Armenia, Armenian Genocide by Ottoman Turkey 1915: Testimony of Survivors-Collection of Documents (Yerevant: Zangak Publishing House, 2013), 19.

${ }^{121}$ No. 23 Mkrtich Alsanian on massacre of township of Akants-Archesh in Archesh District of Van, (testimony taken 23 Aug. 1916, Oshakan), in Armenia, Testimony of Survivors, 72.

${ }^{122}$ No. 17 Sanam Vardanian; Hamlet of Berkri in Berkri District of Van (testimony taken 6 Aug. 1916, Mazra), in Armenia, Testimony of Survivors, 72. 
by cattle or sheep. Destroyed Armenian churches can still be found in Eastern Turkey in use as stables. ${ }^{123}$

The forcible conversion of women and children, with forced marriages of girls and young women to Muslim men, formed a fundamental component of the genocide and demonstrates how the removal of freedom of religion can be used as a genocidal act. ${ }^{124}$ Those who refused to convert were raped and/ or killed. ${ }^{125}$ After deportations of Armenians in later stages of the genocide to what is now northern Syria, many women and children were forcibly converted; some women were converted by Kurds and subsequently compelled to have their faces and hands tattooed as per local tradition ('deq').

The Armenian Genocide left behind up to 200,000 orphans: ${ }^{126}$ 'At wars end, Western aid officials and the Armenian ecclesiastical leadership estimated that the numbers of non-Muslim children housed in Ottoman State orphanages or in Muslim households was at least sixty thousand', with no attempt made to find and reunite children with living relatives. ${ }^{127}$ These orphans ended up in orphanages in Armenia or other countries; some were adopted. Those adopted by non-Armenian families were thus not raised within the Armenian Church. ${ }^{128}$

\section{Violations during the Holocaust}

In Nazi Germany, Jews were targeted not as a religious group, but as a racial group. Jews were considered 'non-Aryan', and Aryan was regarded as a race.

${ }^{123}$ Such as the St Karapet Church at Avarabank Monastery.

${ }^{124}$ Or an 'offering' to convert for 'safety'; Kévorkian, The Armenian, 296; Vahakn N. Dadrian, 'Children as Victims of Genocide: The Armenian Case', Journal of Genocide Research 5, no. 3 (2003): 422-35; Taner Akçam, 'Deportation and Massacres in the Cipher Telegrams of the Interior Ministry in the Prime Ministerial Archive (Başbakanlık Arşivi)', Genocide Studies and Prevention 1, no. 3 (2006): 310-11; Keith David Watenpaugh, “The League of Nations” Rescue of Armenian Genocide Survivors and the Making of Modern Humanitarianism, 1920-1927', The American Historical Review 115, no. 5 (2010): 1324-26; Lorne Shirinian, 'Orphans of the Armenian Genocide with Special Reference to the Georgetown Boys and Girls in Canada, in The Armenian Genocide Legacy, ed. Alexis Demirdjian (London: Palgrave, 2016), 46.

125 See for example, No. 37 Sara Muradian [F] on massacre at village of Boghanis in Gyavash District (testimony taken 1916, Baku), in Armenia, Testimony of Survivors, 92. Many other testimonies recorded mention forced conversions to Islam (often with the subsequent enslavement of the women).

${ }^{126}$ Shirinian, 'Orphans of', 45.

${ }^{127}$ Keith David Watenpaugh, “Are There Any Children for Sale?”: Genocide and the Transfer of Armenian Children (1915-1922), Journal of Human Rights 12, no. 3 (2013): 292; Watenpaugh, 'Rescue of Armenian', 37-39.

128 Watenpaugh, 'Transfer of Armenian', 294. 
Nazis were motivated by decades of changing theory about 'race' and the idea of preserving German 'racial purity.' ${ }^{129}$ Law and decrees passed in Nazi Germany and occupied territories used the terms 'race' and 'non-Aryan' when implementing anti-Jewish laws and policies. ${ }^{130}$

Due to Nazi infatuation with 'race', the Jewish religion experienced relative freedom under Nazi rule. In ghettos, religion continued to be a major part of life for the Jews therein. Religious ceremonies were still undertaken, such as evening services and weddings. Sabbath and Jewish holy days were observed, Torah study took place, and religious education for children took place. ${ }^{131}$ Some ghettos had synagogues. Continuation of religious rituals served to help ghetto inhabitants retain some element of normality, routine, and community.

Religion was not necessarily restricted or even banned in concentration and death camps. Prisoners in Belzec had prayer shawls and tefillin, and prayed in their barracks at night. ${ }^{132}$ In Treblinka, evening services were held, with SS guards listening to the melodic voice of the Kapo who ran the service. Treblinka prisoners also had shawls and tefillin, along with prayer books, and were permitted morning and evening prayers. Minyan was permitted in the carpentry workshop in the morning and evening before and after work. In bitter irony, the SS also permitted funerals in some instances, including erection of headstones. Weddings were even held, matzot baked for Passover, and the Kol Nidre service

${ }^{129}$ Karl A. Schleunes, The Twisted Road to Auschwitz: Nazi Policy Towards German Jews 1933-139 (Urbana and Chicago: University of Illinois Press, 1990), 15-35.

${ }^{130}$ See, for example, Germany: Harry Reicher, Law and the Holocaust: Cases and Materials, 4th ed. (Philadelphia: University of Pennsylvania Law School, 2001); Janos Pelle, Sowing the Seeds of Hatred: Anti-Jewish Laws and Hungarian Public Opinion, 1938-1944 (Boulder: East European Monographs, 2004); Vera Ranki, The Politics of Inclusion and Exclusion: Jews and Nationalism in Hungary (St Leonards: Allen and Unwin, 1999); Nathaniel Katzburg, 'Anti-Jewish Legislation in Hungary 1940-1941', Annual of Bar-Ilan University Studies in Judaica and the Humanities XVI-XVII (1979): 86-87. Italy: Liliana Picciotto Fargion, 'The Anti-Jewish Policy of the Italian Social Republic (1943-1945)', Yad Vashem Studies 17 (1986): 17; Renzo De Felice, The Jews in Fascist Italy: A History (New York: Enigma Books, 2001), 337. Ironically, under French law 26 Apr. 1941 Troisième Ordonnance relative aux mesures contre les juifs, race was defined by religion: a person was considered ipso jure as pure Jewish if one grand-parent was part of the Jewish religious community; Philippe Héraclès, La Loi Nazie en France (Paris: Guy Authier Editeur, 1974), 180-81; J. Lubetzki, La Condition des Juifs en France sous L'Occupation Allemande 1940-1944 (Paris: CDJC, 1945), 137-38, 58-61, 65-70.

131 Yitzhak Arad, The Pictorial History of the Holocaust (Jerusalem: Yad Vashem, 1990), 124, 26-27.

132 Yitzhak Arad, Belzec, Sobibor, Treblinka: The Operation Reinhardt Death Camps (Bloomington and Indianapolis: Indiana University Press, 1987), 217. 
held for Yom Kippur. ${ }^{133}$ The Kaddish was very commonly and frequently recited in camps, given the high number and daily occurrence of deaths. ${ }^{134}$ In one incident at Auschwitz, 2,000 prisoners recited the Viddui with no reaction from SS guards watching. ${ }^{135}$ Auschwitz prisoners were able to access prayer books and tefillin. ${ }^{136}$

It should be noted, though, that the permissiveness of the Nazis towards Jewish religious practice was not based on any mercy or concession, but rather because the Nazis assumed the Jews would be killed anyway. The ultimate goal was to eradicate not only the Jewish people but the entire existence of Jewish history, culture, and religion. Thus, individual Jews or groups of Jews practicing religious tradition was irrelevant because they were going to be completely annihilated, including their religion.

Regardless of the fact that Jews were not targeted specifically as a religious group and were still permitted to conduct religious rituals, freedom of religion was nonetheless impeded. Jewish markers such as beards on religious men were often cut or pulled off as an act of humiliation. Jewish religious monuments and property were destroyed. Synagogues were prime targets for destruction. During the 9-10 November 1938 Reichspogromnacht (or Kristallnacht), in addition to Jewish houses and businesses, synagogues were attacked, with windows broken and many set on fire, under orders of Josef Goebbels. ${ }^{137}$ An estimated 1,400 synagogues and prayer rooms throughout the German Reich were destroyed or burned. ${ }^{138}$ Religious icons such as Torah scrolls were desecrated and furniture smashed. Synagogues in the Polish city of Łódź, for example, were dismantled and burned early on under Nazi occupation (1939 and 1940). ${ }^{139}$

In ghettos, Sabbath and holy days were observed where possible, however the Germans did not honour these festivals and rituals. Indeed, ghetto inhabitants

133 Arad, Belzec, Sobibor, 216-17.

${ }^{134}$ Arad, Belzec, Sobibor; Filip Müller, Eyewitness Auschwitz: Three Years in the Gas Chambers (Chicago: Ivan R. Dee, 1979), 48. Recounts one incident in Auschwitz when another inmate recited the Kaddish as they cremated Müller's own father.

135 Ibid., 70-71. Prayer and song permission may have been allowed in order to calm victims before their deaths.

136 Ibid., 35.

137 Saul Friedländer, Nazi Germany and the Jews 1933-1939: The Years of Persecution (London: Phoenix, 1997), 272-74.

138 Arad, Pictorial History, 54-59.

139 Shimon Huberband, 'The Destruction of the Synagogues in Łódź', in Łódź Ghetto: Inside a Community Under Siege, eds. Alan Adelson and Robert Lapides (New York: Viking, 1989), 70-71. See also photographic evidence as taken by Henryk Ross such as Henryk Ross, 'Ruins of a Destroyed Synagogue on Wolborska Street, Which was Blown up by the German Authorities, United States Holocaust Memorial Museum, https://collections .ushmm.org/search/catalog/pa1054357. 
were forced to work on these holy days, and at times Aktionen were carried out specifically on these days, as a way of deliberately disrupting Jewish life and community. ${ }^{140}$

In addition to these overt acts, in some circumstances children had to suppress their Jewish identity, ${ }^{141}$ even converting to other religions such as Catholicism. ${ }^{142}$ For example, in France, children were hidden with families or in convents and converted to Catholicism, either during the war or afterwards when their families did not return. Some children did not even know they were Jewish, and discovering this led to identity crises for those who had been raised in a Catholic family or convent; some even rejected their Jewishness for fear of persecution. ${ }^{143}$ Moreover, some children as sole survivors of their family lived with non-Jewish families, into which they were adopted after the war. Through no fault of their own or the families they ended up living with, the children were unaware of their Jewish heritage and grew up under a different or no religion. ${ }^{144}$ The numbers of these children is unknown, but, like the Armenian Genocide, this demonstrates the long-term impact that genocide can have on freedom of religion, even after killing has stopped.

\section{Violations during the Cambodian Genocide}

Under the Khmer Rouge regime from 1975 to $1979,1.7$ million people died. ${ }^{145}$ While it has been argued that the Khmer Rouge killings did not amount to

140 Arad, Pictorial History, 124.

141 Vicki Gordon, 'The Experience of Being a Hidden Child Survivor of the Holocaust' (Doctor of Philosophy University of Melbourne, 2002), 140-41, http://hdl.handle.net/11343/39539.

${ }^{142}$ One of Gordon's interview subjects, D, notes that in Budapest, Hungary, she and her sister took classes to convert to Christianity, to save themselves; and that even the Chief Rabbi had an honorary conversion. D did not want to continue the classes, even though she risked her own survival; Ibid., 242. Another subject, $P$, notes that 'a great number of Hungarians became Catholic'; Ibid., 325.

143 Ibid., 155-57.

${ }^{144}$ Gordon's interview subject, $\mathrm{P}$, took conversion classes later in life, to relearn about Judaism; Ibid., 325. The author of this chapter interviewed a child survivor of the Holocaust (including camps) who was ultimately adopted by a Jewish family in the USA. However, she had almost been adopted by a Christian family in Sweden where she was in a refugee camp. It was only by luck that she was raised in her original faith. Interview with Rina, Jerusalem, Jan. 2013.

145 Sliwinski's study estimates a death toll of 24 per cent to 25.6 per cent of the early 1975 population by 1979 , the majority of whom died through execution or famine/exhaustion, or disappeared; Marek Sliwinski, Le Génocide Khmer Rouge: une analyse démographique (Paris: l'Harmattan, 1995), 60. 
genocide, ${ }^{146}$ this article takes the view that genocide did take place under the Khmer Rouge, with the intent being to destroy in part the Khmer people, ${ }^{147}$ in addition to destruction of certain minority groups, including Vietnamese, ethnic Chinese, and Muslim Cham. ${ }^{148}$

The dominant religion in Cambodia was Buddhism. The main group of people targeted by the Khmer Rouge were 'city people', or intellectuals. However, religious and minority nationality groups were also marked groups. Khmer Rouge communist ideals excluded religion completely. Consequently, freedom of religion was almost completely and at times violently restricted, with a goal to eliminate religion. ${ }^{149}$

'Reactionary' religions were banned under the Constitution of Democratic Kampuchea. ${ }^{150}$ Buddhism was seen as a reactionary religion because it had passivity and lacked interest in collective construction of the country. However,

Kiernan estimates the death toll at 21 per cent; Ben Kiernan, The Pol Pot Regime: Race, Power, and Genocide in Cambodia Under the Khmer Rouge, 1975-79, 3rd ed. (New Haven: Yale University Press, 2008), 458.

${ }^{146}$ For example, William A Schabas, 'Problems of International Codification: Were the Atrocities in Cambodia and Kosovo Genocide?' New England Law Review 35, no. 2 (2001): 287-302; William A Schabas, 'Cambodia: Was it Really Genocide?’ Human Rights Quarterly 23, no. 2 (2001): 470-77.

${ }^{147}$ For discussion of the composition of the partial group, see Marcelo Ferreira, 'Genocide, and its Definition as the "Partial Elimination of a National Group", Genocide Studies and Prevention 8, no. 1 (2013): 14-16.

${ }^{148}$ For example, Kiernan, Pol Pot Regime, 460-63; Ysa Osman, The Cham Rebellion (Phnom Penh: Documentation Center of Cambodia, 2006), 119. The Extraordinary Chambers in the Courts of Cambodia convicted Khieu Samphan and Nuon Chea of charges of genocide with regards to the minority groups, the Muslim Cham and Vietnamese, in Case 002/02 Judgement (16 Nov. 2018). For specific reference to the genocide of the Khmer in part, see Ben Kiernan, 'The Cambodian Genocide, 1975-1979', in Centuries of Genocide: Essays and Eyewitness Accounts, eds. Samuel Totten, and William S. Parsons (New York: Routledge, 2012), 325. Also note that while religious persons/leaders were particularly targeted for annihilation under the Khmer Rouge, foreign religious leaders were permitted to flee. Ponchaud describes the separation of Khmer Catholic monks and nuns from foreign (mostly French) ones, the latter being rescued by the French embassy; François Ponchaud, La Cathédrale De La Rizière: Histoire De Leglise Au Cambodge (Paris: CLD éditions, 2000), 205.

149 Kiernan, 'The Cambodian', 322.

150 Article 20 'Every citizen of Kampuchea has the right to worship according to any religion and the right not to worship according to any religion. Reactionary religions which are detrimental to Democratic Kampuchea and Kampuchean people are absolutely forbidden'. 
Buddhism was also a significant source of power in Khmer culture, with village life revolving around the temple(s). It was a source of authority and power that could threaten the authority of Angkar ('the Organisation', as the Khmer Rouge termed itself). ${ }^{151}$

Consequently, Buddhist monks were de-robed; those who refused to do so were tortured and killed. ${ }^{152}$ Monks who de-robed undertook forced labour with the rest of the population. ${ }^{153}$ Religious practice was banned, in particular funerals and giving alms. However, some ceremonies still took place. These were the ceremonies involving the donation of money, the majority of which was afterwards stolen by Khmer Rouge cadres. ${ }^{154}$ There are instances of the practice of secret rites where possible, but these activities were rare due to the danger of carrying them out.

Forced marriage took place under the Khmer Rouge. These 'marriages' were not carried out according to Khmer Buddhist tradition, but rather a group 'marriage' pledging allegiance to Angkar. Survivors who were forced into these 'marriages' consistently note their distress at the fact the marriage was not carried out according to traditional rites with family present. ${ }^{155}$

Temples were ransacked and repurposed, with valuable statues stolen and temples converted into military offices, rice storage, or pigsties, or dismantled

${ }^{151}$ François Ponchaud, Cambodge année zéro (Paris: Editions Kailash, 2012), 146, 269-70. This is despite the fact that, ironically, the Khmer Rouge initially incorporated Buddhist concepts into their ideology in order to win over the Khmer people; Ibid., 276, 277.

${ }^{152}$ Kiernan, 'The Cambodian', 323. 'The Khmer Rouge didn't believe in Buddhism and wanted to eliminate it. They didn't need monks and didn't want people to celebrate any festivals. One monk in our village refused to disrobe, so they came in the middle of the night, tied him to a banana tree, and killed him', Eng Sam Ol in Wynne Cougill with Pang Pivoine, Ra Chhayran, and Sim Sopheak, Stilled Lives: Photographs from the Cambodian Genocide, trans. by Chy Terith (Phnom Penh: Documentation Center of Cambodia, 2004), 31; see also other testimonies at 72-73, 76. Ian Harris, Buddhism Under Pol Pot (Phnom Penh: Documentation Center of Cambodia, 2007), 122-27, 34-35; Chanthou Boua, 'Genocide of a Religious Group: Pol Pot and Cambodia's Buddhist Monks', in State Organized Terror: The Case of Violent Internal Repression, ed. P. Timothy Bushnell (Westview Press, 1991), 232-5.

153 Ponchaud, Cambodge année, 147-9; Harris, Buddhism Under, 114-6; Boua, 'Genocide of', 236-37.

${ }_{154}$ Harris, Buddhism Under, 145-50.

155 See for example, testimonies before the Extraordinary Chambers in the Courts of Cambodia, Case 002/02, transcript, Witness 2-TCCP-274, 22 and 23 Aug. 2016; Witness 2-TCCP-224, 23 and 24 Aug. 2016; Witness 2-TCCP286, 30 Aug. 2016; Witness 2-TCCP-1064, 24 Oct. 2016. 
for other use. ${ }^{156}$ Non-valuable religious objects such as statues, books, and manuscript were destroyed, including book burnings. ${ }^{157}$ Propaganda expounded Buddhist monks as leeches and imperialists. ${ }^{158}$

Islam was specifically targeted too, considered a 'polluted and inferior religion. ${ }^{159}$ Profanation of mosques and graves took place; sacred texts were destroyed. ${ }^{160}$ Muslims were forced to change their names to ones that were 'less Muslim sounding' and to eat pork (refusal for which resulted in arrest, torture, and death). ${ }^{161}$ Religious books such as the Quran were destroyed, Qur'anic schools closed down, and religious practices such as visiting shrines or Quranic recitation forbidden. ${ }^{162}$ As with Buddhist practices, some people prayed in secret, despite the significant risk. ${ }^{163}$ The destruction of Muslim identity 'was abrupt, brutal and widespread.' ${ }^{164}$

Catholic and Christian churches were not immune: many were razed to the ground; for example, the Phnom Penh cathedral was blown up and replaced with a garden. ${ }^{165}$ In Battambang, the cemetery was also destroyed. ${ }^{166}$ All Catholic Church leaders and eleven evangelical pastors were executed or died from starvation or fatigue. ${ }^{167}$

All persons of faith and religious leaders were subject to forced de-conversion. They were made to wear secular clothing (the typical all-black attire of the regime), and to have their hair cut according to regime regulations. ${ }^{168}$

Religious leaders of all faiths were tortured and killed, including Buddhist monks, Muslim leaders, and Islamic teachers. ${ }^{169}$ Marek Sliwinski estimates the

${ }_{156}$ Ponchaud, Cambodge année, 151; Harris, Buddhism Under, 154-67

157 Harris, Buddhism Under, 162-69.

158 Ponchaud, Cambodge année, 149-51.

159 Farina So, The Hijab of Cambodia: Memories of Cham Muslim Women after the Khmer Rouge (Phnom Penh: Documentation Center of Cambodia, 2011), 55.

${ }^{160}$ François Ponchaud, La Cathédrale de la Rizière: Histoire de l'Eglise au Cambodge, 2nd ed. (Paris: CLD éditions, 2006), 271; So, Hijab of, 54-55.

${ }^{161}$ Kiernan, Pol Pot Regime, 461; Ponchaud, La Cathédrale, 271; Osman, The Cham Rebellion, 115. Changing names was either to another Cham Muslim name, to a Khmer name, or by shortening the original name, to hide identity; So, Hijab of, 61-62.

${ }^{162}$ So, Hijab of, 54-55, 57.

163 Ibid., 59-61.

${ }^{164}$ Ibid., 64.

${ }^{165}$ Ponchaud, La Cathédrale, 239.

166 Ibid., 240, 60.

167 Ibid., 239, 65.

${ }^{168}$ So, Hijab of, 61-62.

169 Ben Kiernan, 'Genocidal Targeting: Two Groups of Victims in Pol Pot's Cambodia', in State Organized Terror: The Case of Violent Internal Repression, 
mortality rate at 29.8 per cent for Buddhists, 40.6 per cent for Muslim Cham, and 48.6 per cent for Catholics. ${ }^{170}$ In $1975,0.18$ per cent of Cambodians had a religious profession; this was reduced to only 0.03 per cent by $1976 .{ }^{171}$ Chanthou Boua estimates that fewer than 2,000 of Cambodia's 65,000-70,000 monks survived. ${ }^{172}$

Destruction of Buddhism was particularly significant in Cambodia, where the essence of Khmer culture was Buddhism. François Ponchaud writes: 'Until April 1975, "race" and "religion" were expressed using the same word, and in the everyday language, saying "khmer" meant "Buddhist" ... it is at the temple where Khmers rediscover their khméritude. ${ }^{173}$ In capturing the minds of young Khmer people, Buddhism was lost to the younger generation, who embraced the violence of the communist revolution and not the values of Buddhism. In eliminating Buddhism, Angkar sought to eliminate the Khmer as they existed, creating a completely new Khmer nation by radically transforming their culture. ${ }^{174}$

\section{Freedom of religion and genocide: definition and prevention}

These case studies show clear violation of multiple aspects of the right to freedom of religion. All three regimes restricted or prohibited the right to manifest religion or belief through worship, observance, practice, and teaching, through destruction of buildings, banning of religious rites and rituals, closure of religious education, and killing of religious leaders. The absolute right to not be coerced was violated in the Armenian and Cambodian genocides, through forcible conversion. Under the Nazis, people converted to Christian religions as a means of saving themselves; this is also coercion, conversion out of desperation rather than true choice. ${ }^{175}$ All restrictions on religion in the Armenian Genocide and the Holocaust were carried out as discrimination against minorities.

ed. P. Timothy Bushnell (Westview Press, 1991), 223; Harris, Buddhism Under, 131-33; So, Hijab of, 54.

170 Compared with an estimated overall death rate of 21-24 per cent of the general population. Sliwinski, Le Génocide, 76-77. Ponchaud provides numbers from specific communities, with some losing up to two-thirds of their Catholic population; Ponchaud, La Cathédrale, 259-65.

171 Sliwinski, Le Génocide, 92.

172 Boua, 'Genocide of', 239.

173 Ponchaud, Cambodge année, 145-271 (author’s translation).

${ }^{174}$ For discussion on the inherent connection between nationalism and Buddhism in Cambodia, see John Marston and Elizabeth Guthrie, eds., History, Buddhism and New Religious Movements in Cambodia (Honolulu: University of Hawai'i Press, 2004).

175 Of course, if their true identity was discovered, conversion did not save the converted Jews, because Jewishness was in the 'blood' and had to be destroyed. 
In the Cambodian Genocide, Buddhists were the majority group but minority religions such as Islam and Catholicism were discriminated against. These restrictions were not implemented as legitimate limitations for public safety, order, health or morals; ${ }^{176}$ rather to specifically discriminate and destroy.

Raphael Lemkin delineated 'religious techniques' as a specific part of genocide, along with political, cultural, economic, biological, physical, and moral. ${ }^{177}$ Steven Leonard Jacobs found "religion" is all too often overlooked as an important factor in contributing to either the implementation and perpetuation of genocide, or as a foundational underpinning and rationalization for such collective acts.' ${ }^{\prime 78}$ Leo Kuper has written of this distinct role of religion in the dehumanisation process within genocide:

It is striking that the cases of genocide discussed [in this book], with a few exceptions ... are marked by religious differences between the killers and the victims. This suggests that religious values (even among those who are not devout and in conflicts quite unrelated to matters of faith) may be ideologically significant at a different level, shaping sentiments of exclusion, and derogatory stereotypes of the followers of other religions. And it suggests too that we underestimate the contemporary significance of religion in genocide. ${ }^{179}$

More recently, Kate Temoney examined the role of religion in genocide, focusing on Rwanda and Bosnia. ${ }^{180}$ She categorised four broad roles of religion in genocide: a religious group being targeted; use of religionised language by perpetrators; the condonation of genocide explicitly or implicitly by religious leaders; and the role of religious groups in preventing or interrupting genocide. Temoney determined: 'although religious belief is rarely the only driving factor in genocide, it is not merely ancillary to genocide but potentiates genocide in

176 Such limitations or derogations are permissible under human rights law during public emergency; see, for example, Article 4 of the International Covenant on Civil and Political Rights; and Olivier de Schutter, International Human Rights Law: Cases, Materials, Commentary, 2nd ed. (Cambridge: Cambridge University Press, 2014), 339-426.

177 Raphael Lemkin, Axis Rule in Occupied Europe (Washington DC: Carnegie Endowment for International Peace, 1944), 89.

178 Steven Leonard Jacobs, 'Introduction: Genocide in the Name of God: Thoughts on Religion and Genocide', in Confronting Genocide: Judaism, Christianity, Islam, ed. Steven Leonard Jacobs (New York: Lexington Books, 2009), ix.

179 Kuper, Genocide, 90.

${ }^{180}$ Kate Temoney, 'Religion and Genocide Nexuses: Bosnia as Case Study', Religions 8, vol. 6 (2017), 112-25; Kate Temoney, 'The 1994 Rwandan Genocide: The Religion/Genocide Nexus, Sexual Violence, and the Future of Genocide Studies', Genocide Studies and Prevention 10, no. 3 (2016): 3-24. 
a particular manner.' ${ }^{181}$ Religion thus becomes an inherent and critical part of the 'othering' aspect of genocide. I would add to Temoney's list a fifth broad role of religion in genocide: religion as a specific target of discrimination and rights violations (occurring even when a group is not targeted as a religious group).

Preservation of religious rituals in targeted groups continued where possible for normality and routine, but also as a form of resistance. ${ }^{182}$ Safeguarding culture and rituals was a means of survival through perpetuation of that group's existence as it is existed as a separate and distinct cultural entity. While not all members of the targeted group may have been religious, the particular religion of their group was a significant component of their group as it existed culturally and whether defined as nation, race or ethnicity.

The example of the Cambodian Genocide is particularly noteworthy, where we see Buddhism targeted separately from 'urban people', both part of Khmer society. To destroy Buddhism was to destroy Khmer, and part of the reparation of Khmer society post-1979 was rehabilitation of the ritual life of their community. This rehabilitation was also necessary for Armenians and Jews.

Thus, destroying religion was part and parcel of destroying a group, in whole or in part: destroying that group as a social structure. Religion and the freedom to practice are substantial elements of this social structure or figuration, and thus require elimination if a group is to be extinguished. When genocide is committed, it is done so for the purpose of destruction (in whole or in part) of a group of people based on their nationality, ethnicity, race, or religion. ${ }^{183}$ As Christopher Powell noted, destroying a group is not killing multiple individuals, but rather eradicating 'something more than or other than the sum of the individuals who belong to it ... genocide is the killing or destruction of that "something more". ${ }^{184}$ That is, the 'genos' in genocide 'must connote a type of social figuration. The collective object ... must ... have the general property of being a dynamic relational network formed through practical social interactions in historical time. ${ }^{185}$ Daniel Feierstein has referred to genocide as 'a specific technology of power for destroying and reorganizing social relations', observing that it 'is impossible to commit genocide without first building models of identity and Otherness. ${ }^{186}$

181 Temoney, 'Religion and', 3.

182 Stanislav Zámečník, That Was Dachau 1933-1945 (Brussels: Comité International de Dachau, 2004), 307.

${ }^{183}$ For a discussion of 'groups' in the purview of genocide, see William A Schabas, Genocide in International Law, 2nd ed. (Cambridge: Cambridge University Press, 2009), 117-71.

${ }^{184}$ Christopher Powell, 'What do Genocides Kill? A Relational Concept of Genocide', Journal of Genocide Research 9, no. 4 (2007): 524

185 Ibid., 538.

${ }^{186}$ Daniel Feierstein, Genocide as Social Practice (New Brunswick: Rutgers University Press, 2014), 205-09. 
Claudia Card describes genocide as social death, different from simply killing large number of people through, for example, terrorism, or war. ${ }^{187}$ Social death comes through annihilation of social vitality, which only exists through relationships, including those mediated through social institutions such as religion. ${ }^{188}$ Members of the group lose their context and identity that shapes their lives. ${ }^{189}$ Card notes:

In genocides, survivors experience a social death, to a degree and for a time. Some later become revitalised in new ways; others do not. Descendants of genocide survivors, like descendants of slaves who were kidnapped, may be "natally alienated," no longer able to pass along and build upon the traditions, cultural developments (including languages), and projects of earlier generations. ${ }^{190}$

The International Criminal Tribunal for the former Yugoslavia Appeals Chamber specifically noted that the goal of génocidaires is 'to deprive humanity of the manifold richness its nationalities, races, ethnicities and religions provide'; in other words, it is the group as a cultural concept, a social structure that génocidaires seek to eliminate. ${ }^{191}$ Lemkin created the term genocide as a word to capture 'the destruction of essential foundations of the life of national groups', however did not necessarily see killing as the crucial component of that destruction. Instead, he saw the plan of destruction as encompassing the disintegration of political and social institutions, of culture, language, national feelings, religion, and the economic existence of national groups, and the destruction of the personal security, liberty, health, dignity, and even the lives of the individuals belonging to such groups. ${ }^{192}$ Lemkin considered loss of life as the extreme end of genocide, but not the point around which the other crimes pivoted. ${ }^{193}$ His focus was the social structure of the targeted communities, the

187 Claudia Card, Confronting Evils: Terrorism, Torture, Genocide (Cambridge: Cambridge University Press, 2010).

188 Card, Confronting Evils, 237.

189 Ibid., 254.

190 Ibid., 262. See also Shmuel Lederman, 'A Nation Destroyed: An Existential Approach to the Distinctive Harm of Genocide', Journal of Genocide Research 19, no. 1 (2017): 112-32.

191 Prosecutor v Krstić, IT-98-33-A, Appeals Judgement (19 Apr. 2004), 12, para. 36.

192 Lemkin, Axis Rule, 79; Schabas, Genocide in, 30.

${ }^{193}$ Lemkin framed the social, cultural and economic aspects of genocide and the 'biological aspect', which was 'physical decline and even destruction of the population involved'; Lemkin, Axis Rule, 80. In addition to these aspects, he also included religious and moral genocide techniques; Ibid., $82-90$. 
removal of rights from that group, and 'the imposition of the national pattern of the oppressor' on the oppressed group. ${ }^{194}$

Considering the specific fixation on the religion of a group, regardless of how the perpetrator categorises that group designated for destruction, enables adoption of a broader interpretation of the definition of genocide. Rather than a separate concept of 'cultural genocide', the essential destruction of a group includes destruction of identity, not just physical elimination. Indeed, to fall under the ambit of the Genocide Convention, a group is required to have a perspicuous identity. 'Genocide not only intentionally strips individuals of the ability to participate in social relationships, activities, and traditions, it aims to destroy the possibility of those particular kinds of relationships, activities, and traditions for others in the future. ${ }^{195}$ For survivors, there is alienation, deracination, from their people-their group.

Genocide is defined as acts committed with intent to destroy a group in whole or in part. The Genocide Convention and ICC definition requires acts be committed 'with intent to destroy'. One of the crimes of genocide is infliction of conditions of life calculated to bring about 'the physical destruction in whole or in part' of the group. The fact that the umbrella definition does not include the word 'physical' but one of the specific crimes does, indicates that interpretation of 'intent to destroy' can be broader than simply physical destruction. ${ }^{196}$ International and domestic case law has referred to the bonds of group members as a defining element of the group, 'as well as such aspects of the group as its members' culture and beliefs', hence the 'intent to destroy' 'cannot sensibly be regarded as reducible to an intent to destroy the group physically or biologically' ${ }^{197}$

Violations of freedom of religion are genocidal crimes: causing serious bodily or mental harm, forcible transfer of children, and killing members of the group. Most violations are the former-impediments to exercising freedom of religion result in or constitute serious bodily or mental harm, destroying the social structure of that group. For example, tattooing of Armenian Christian women amounts to serious bodily and mental harm; destruction of religious buildings and icons generates serious mental harm; forced conversion creates serious mental harm; and cessation of religious rites and rituals also results in

${ }^{194}$ Lemkin, Axis Rule, 79.

195 Card, Confronting Evils, 265.

${ }^{196}$ For further discussion on treaty interpretation in the context of the crime of genocide, see Elisa Novic, "Physical-biological or Socio-cultural 'Destruction' in Genocide? Unravelling the Legal Underpinnings of Conflicting Interpretations," Journal of Genocide Research 17, no. 1 (2015): 70-73.

197 Prosecutor v Krajišnik, IT-00-39-T, Trial Judgement (27 Sept. 2006), 302, para. 854, fn. 1701. See also John Quigley, The Genocide Convention: An International Law Analysis (Aldershot: Ashgate, 2006), 103-05. 
serious mental harm. Forcible transfer of children sometimes occurs specifically for the purposes of forced conversion (as in the Armenian Genocide).

Taking a more expansive interpretation of the crime of genocide will enable international criminal courts and tribunals to prosecute more perpetrators of genocide, reducing impunity of perpetrators for these significant and enduring crimes. Attentiveness to violations of freedom of religion in the context of genocide is crucial, where perpetrators can be punished for causing serious bodily or mental harm for crimes committed that are also rights violations. There is a compelling obligation to look beyond torture and killing in genocide, to human rights violations amounting to genocide crimes that have frequently been neglected for prosecution in favour of prosecuting crimes of torture and killing. Focus on physical destruction in prosecutions ignores the seriousness of crimes that destroy the very fabric of a group, crimes that are 'a deliberate attempt to change the identity of the survivors by modifying relationships within a given society.' ${ }^{\prime}$

Recognition of the role of religious freedom in the genocide process also has repercussions for genocide prevention. The case studies assessed here demonstrate violations of the right to freedom of religion take place in genocides even if the targeted group is not exclusively a religious group, and well before killing begins. There are distinct similarities in the way that freedom of religion is violated in the genocide process: destruction of religious icons, buildings, and texts; restriction of or complete banning of religious rites, rituals, and ceremonies; prohibition of religious education; forced conversion; and specific targeting of religious leaders for torture and killing. These consistent patterns position the right to freedom of religion as a potentially significant genocide indicator/risk factor (within the broader context of human rights violations more generally).

There is a need for specific scrutiny of violations of religious rights in assessing genocide risk factors. These rights violations can also be used to deepen interpretations of the definition of genocide by international criminal courts and tribunals. Violations of freedom of religion thus have the potential to play a significant role in prevention and punishment of genocide. The importance of this particular rights violation should not be underestimated, and therefore freedom of religion should be staunchly and consistently protected at domestic and international levels.

${ }^{198}$ Feierstein, Genocide as, 12. 